\title{
INDONESIAN TERTIARY STUDENTS' ATTITUDES TOWARDS THE USE OF LOCAL CULTURE VS TARGET CULTURE READING MATERIALS IN ENGLISH READING CLASS
}

\author{
Rojab Siti Rodliyah \\ Ernie D.A. Imperiani \\ Lulu Laela Amalia \\ English Education Department FPBS Universitas Pendidikan Indonesia \\ Address: Jln. Dr. Setiabudhi 229Bandung 40154 West Java \\ Email: rojab.siti@gmail.com
}

\begin{abstract}
Abstrak
Tulisan ini bertujuan untuk mengungkap bagaimana sikap mahasiswa Indonesia terhadap penggunaan materi dengan muatan budaya lokal maupun budaya target dalam teks bahasa Inggris di kelas Membaca (Reading) terkait dengan peran terkini dari bahasa Inggris. Sudah dikenal luas bahwa peran terkini dari bahasa Inggris adalah sebagai bahasa internasional dan lingua franca. Dengan perannya sebagai bahasa internasional, idealnya pengajaran dan pembelajaran bahasa Inggris disesuaikan dengan pendekatan pedagogik yang sesuai seperti pendekatan pedagogik (bahasa Inggris sebagai bahasa internasional yang selanjutnya disingkat dengan EIL). Dengan kata lain, pengajaran dan pembelajaran EIL harus berbeda dengan pengajaran dan pembelajaran bahasa kedua atau bahasa asing lainnya. Berhubung Indonesia termasuk dalam kategori negara yang menggunakan bahasa Inggris sebagai bahasa asing (EFL country), maka penelitian ini menarik untuk dilakukan untuk mengetahui apakah ada implikasi terhadap pengajaran bahasa Inggris seperti di kelas membaca bahasa Inggris di negara ini. Subjek penelitian ini adalah mahasiswa Jurusan Pendidikan Bahasa Inggris tingkat 1. Pengumpulan data penelitian ini didapatkan dari kuesioner dengan Likertscale tentang sikap mahasiswa terhadap materi/teks yang diajarkan selama 1 semester. Sebagai tambahan, wawancara juga dilakukan untuk mengklarifikasi data dan untuk mendapatkan informasi tambahan. Hasil dari penelitian ini menunjukkan bahwa mahasiswa mempunyai sikap yang positif terhadap penggunaan materi bacaan yang memuat budaya lokal dan budaya bahasa target, meskipun mayoritas memilih materi dengan muatan budaya bahasa target. Selain itu, banyak juga dari mereka yang mengakui pentingnya pemilihan materi bacaan dengan muatan budaya internasional dalam pengajaran bahasa Inggris.
\end{abstract}

Kata-Kata Kunci: EIL, ELF, materi budaya lokal, materi budaya target, sikap mahasiswa

\begin{abstract}
This paper aims at portraying Indonesian tertiary students' attitudes towards the use of local and target culture reading texts in English reading classes with regard to today's role of English. It has been widely recognized that today's role of English is as an international language (EIL) and as a lingua franca (ELF). Regarding this international role of English language, ideally teaching and learning English should be matched with appropriate pedagogical approach, in this case, EIL pedagogy
\end{abstract}


approaches. In other words, teaching and learning EIL should be different from teaching and learning of any other second or foreign languages. Since Indonesia is categorized as an EFL country, it is interesting to find out whether this issue has an impact on ELT practices such as English reading class in this country. The subjects of the study are first year English Education Department students. The data were gained by delivering Likert scale questionnaire to the students on their attitude towards the reading materials given to them in one semester. In addition to this, an interview was conducted to verify the data and gain further information. The findings revealed that in general they show positive attitude to both local culture and target culture reading materials, with the majority of them prefer reading target culture reading materials. Furthermore, a considerable number of the students also acknowledge the importance of the use international culture along with English language teaching.

Key Words: EIL, ELF, local culture material, target culture material, student's attitude

\section{INTRODUCTION}

It is widely accepted fact that today English is a global lingua franca (ELF) and has become an international language (EIL) (Crystal, 1997; McKay, 2003a, 2003b; Seidlhofer, 2004, 2005, and Sharifian, 2009). English has achieved this status because it is not only used among people from English speaking countries, but also used and spoken by a large numbers of people whom English is not their mother tongue.

In response to this international role of English language, ideally teaching and learning English should be matched with appropriate pedagogical approach, in this case, EIL pedagogy approaches. This is in line with what has been suggested by McKay (2003a, 2003b) that teaching and learning EIL should be different from teaching and learning of any other second or foreign languages. What is needed, then, is a paradigm shift (McKay, 2003b, Sharifian, 2009).

One of the important and sensitive issues in EFL classes with regard to EIL is the issue of culture. In English reading class, for example, in which textbooks are seen as important component, English teachers are often confused to decide which culture should be chosen (McKay, 2003a \& Zacharias, 2005). Moreover, since English has become an international language, there seems to be less encouraging to promote target cultural content in teaching materials and there is a growing recognition of the importance of including the local or source culture (McKay, 2003a).

In addition to the issue of culture, attitude has also been regarded as one of the primary factors in successful language learning and acquisition (Sonda, 2011). Specifically, Llurda (2009) also acknowledges the importance of students' attitude toward EIL. Therefore, this study attempts to investigate Indonesian tertiary students' attitudes towards the use of local and target culture reading texts in English reading classes with regard to today's role of English as an international language (EIL).

As suggested by McKay (2003b) and (Sharifian (2009), English as an international language or EIL refers to a paradigm shift in ELT. Its main concern is "the recognition of World Englishes, regardless of which 'circles' they belong to" (Sharifian, 2009, p.2). Further, Seidlhover (2004), Jenkins (2006), McKay (2009a), and Sharifian (2009) believe that instead of suggesting any particular variety to be selected as a lingua franca for international 
communication, EIL recognizes English, with its many varieties, as a language of international which supports intercultural communication. In response to this international role of English language, ideally teaching and learning English should be matched with appropriate pedagogical approach, in this case, EIL pedagogy approaches. As McKay (2003a) points out, teaching and learning EIL should be different from teaching and learning of any other second or foreign languages.

Reading in any language requires three kinds of knowledge which readers use to gain meaning from text: semantic knowledge (knowledge of the world); syntactic knowledge (knowledge of the structure of the language); and graphophonic knowledge (knowledge of sound-letter relationship), as stated by Goodman (1967, cited inGibbons, 2002). Therefore, familiarity with the sound-letter relationship and the structure of the language does not guarantee an effective reading in that language, if it is not supported with the knowledge of the world (semantic knowledge).

This is related to the term schema theory which explains "how the knowledge we have about the world is organized into interrelated patterns based on our previous experiences and knowledge" (Gibbons, 2002, p.78). In reading, schema theory proposes that effective readers draw on particular kinds of culturally acquired knowledge to guide and influence the comprehension process (Anderson \& Pearson, 1984)

Wallace (1992)suggests that the schematic knowledge includes the knowledge of "content" or topic, and the knowledge of the kind of genre. The first type of knowledge or knowledge of content or topic, however, is given less attention by English teachers. This can be seen from the fact that most teachers use ready-made textbooks for their reading subject without considering the content/topic (Zacharias, 2005), despite the importance of this content knowledge as an essential factor that helps EFL students' comprehension of English..

Familiarity with the topic may actually result in students' positive attitude to reading. On the contrary, unfamiliarity with the topic may cause reading difficulties. With regard to this, it is vital that content is taken into account in choosing the materials for reading texts in order to enable students to use all their knowledge altogether to read effectively. Topics related to students' native/local/source culture are likely to attract students' interest than those of the target culture. This is in line with what has been suggested by McKay (2003a) that source/local culture can also encourage students to gain a deeper understanding of their own culture so that they can share their knowledge of their culture when using English with friends from different countries. This is also supported by Luke and Freebody (1990) who consider readers not only as code breakers, but also as text participants, text users and text analyst. As text participants, readers connect the texts with their background knowledge, including knowledge of the world, cultural knowledge, and knowledge of the generic structure.

The importance of background knowledge is underlined by Fisher and Frey (2009) who claim that background knowledge has a profound influence on students' ability to comprehend what they read. This is also supported by the result of a previous study conducted by Lin (2002) about EFL learners' perception of prior knowledge and its role in reading comprehension. The study shows that EFL students in mainland China believe that their vocabulary plays a crucial role in reading comprehension; however, as their linguistic 
knowledge develops, they consider that conceptual and socio-cultural knowledge play a more crucial role in reading comprehension.

The term English as a lingua franca (henceforth ELF) represents the changing ownership of English. Yet, ELF has been interpreted differently. It is seen as an alternative term for EIL in which in one sense, it refers to the local Englishes of those 'non-native English speakers', and in another sense, it refers to the use of English as a means of international communication across national and linguistic boundaries(Jenkins, 2006). However, as Seidlhover (2004, p.210) observes, those two meanings are actually in a "complementary distribution". Even though, ELF researchers prefer the term English as a lingua franca (ELF) to English as an international language (EIL) due to the potential for confusion of the word international, both terms are currently in use (Jenkins, 2006). Furthermore, according to Holliday (2009), ELF is a movement which is related with today's role of English as an international language. Specifically, Holliday (2009) suggests that ELF aims to offer 'non-native speakers' a different model from 'native speakers' of English. McKay (2009a) also points out that ELF interaction refers to the interactions between non-native speakers of English. Nevertheless, it is important to note that ELF interactions also often include speakers of English from both inner and outer circles (Seidlhover, 2004 \& Jenkins, 2006). In addition, although it is expected that the outcome of the English as a lingua franca movement is to develop communication strategy that is sufficient for a successful communication in international settings, it is still a complex issue (Holliday, 2009, Roberts \& Canagarajah, 2009).

Your attitude to something is the way that you think and feel about it, especially when this shows in the way you behave (Cobuild Dictionary, 2006). According to Sonda (2011), there are three components of attitude, namely, affective, cognitive, and behavioral. However, in the context of this study, the term attitude refers to general feelings and responses towards the use of local culture or target culture reading materials in English reading class. Studies looking at students' attitude of English toward different varieties of the language are numerous since they have been considered as important aspect with regard to the international role of English language (Llurda,2009). Nevertheless, according to Llurda (2009), those studies shared a common feature among students of English from different context, which was that they all showed a preference for native speakers' model over their local or non-native speakers' model. A different, yet, interesting finding comes from a recent study carried out by Sonda (2011) who examined Japanese college students' attitudes towards English as an international language (EIL). The results showed that respondents held positive attitudes towards EIL on the whole. The findings also suggested the need to increase the frequency of EIL in students' daily life especially within the Japanese context such as the use of katakana English.

In addition, the issue of teaching 'culture' along with English has also been discussed. One of them is the view which suggests that target language culture should be used in English language teaching to introduce language learner into the cultures of English speaking countries (Byram and Flemming, 1998).On the other hands, with regard to English is now as an international language and as a lingua franca, there are some views that reject the idea of teaching target language culture along with English (McKay, 2003a, 2003b, 2009a; Seidlehofer, 2004; Jenkins, 2006, Sharifian, 2009, and Miftah, 2013).In fact, one of the views supports the use of local culture material 
(the term used by Cortazzi and Jin (1999), refers to learners' own culture as content. In the context of this study, this involved using materials that are based on Indonesian society and culture; therefore, it is expected that students or learners would be familiar with it), while the other view proposes that it should be taught in a culture-free context.

In order to explore the role of 'culture' in English language teaching, several empirical studies have been conducted. Zacharias (2005), for example, investigated the beliefs of tertiary teachers in Indonesia about internationally-published materials. In her study, most of respondents believed that internationally-published materials were preferable to those published locally. In fact, most respondents indicated that the material from English-speaking countries was preferred because they used 'perfect' English despite the international role that English has today. Zacharias (2005) believed that the findings indicate the urgent need for local teachers to be empowered on how to develop their own materials to facilitate their particular learning and teaching situations in relation to the international role of English.

There is also McKay (2009b) who conducted a survey on teachers' opinion on the use of source culture or target culture in Korean English classes. She found that both local culture and target culture have significant impact in Korean English classes. Both of them are useful. Therefore, it is suggested that teachers should make decision when and where to use each culture material to their best advantage.

Another recent study comes from Yilmaz (2010) who examined the opinions of the Turkish English language learners on the role of culture in teaching English as foreign language. The results of the study supported the idea of the importance of 'non-native speakers' of English and the necessity of including local culture in
English language teaching. Moreover, his findings also suggested the importance of international culture materials in addition to local and target culture materials in English language teaching. Target culture materials on the other hand, draw on the culture of a country in which English is spoken as an L1 (Cortazzi\& Jin, 1999). In this case, students would spend most of their time reading and learning about life in native-English speaking countries, such as the United States, Great Britain, and Australia.

The literature review in this research focuses on the issues regarding EIL, ELF, local culture material, target culture material, the nature of reading comprehension, students' attitudes, and teaching cultural content in EFL classes. It also presents some previous studies related to the topic.

\section{METHOD}

This study employed descriptive qualitative design in order to gain more information on students' attitude in English reading class; namely, Reading in Professional Context. This design suits the study because it resulted in giving deep information in the phenomena, In line with this, Creswell (2007) states that qualitative research is "a means for exploring and understanding the meaning individuals or groups ascribe to a social or human problem".

The whole data of this research were taken from both questionnaire and interview. This section discusses the participants who were involved in this study. It also covers the data collection procedures to describe the process of data collection in detail. The participants of this study were 20 university students in their second semester of first year, enrolled in Reading in Professional Context at English Education Department in UPI. Although there is no prerequisite for enrolment in this class, all of the students 
have completed Reading for General Communication that should have been taken in the first semester. The students are; therefore, assumed to have adequate basic language skills.

In the first 3 meetings, they were given ready-made reading texts written by native speakers of English containing a great deal of target culture topics (e.g. thanksgiving, American values, Hellen Keller, etc.). In the next 3 meetings, they were given texts containing local culture topics, (e.g. becak, the history of Dangdut, students' brawl, etc).After the first 3 meetings and the next 3 meetings, the students were given a set of questionnaire to elicit their responses on the reading texts given to them in one semester regarding the cultural elements and the content of the texts in terms of the level of difficulty of the texts and the level of interest of the texts.

The questionnaire consisted of a Likert scale questionnaire on a four point scale (1=strongly agree, $2=$ agree, $3=$ disagree, $4=$ strongly disagree) with a total of 8 items. In addition, a semi-structured interview with the students was conducted to obtain deeper information on their reflections about local culture and target culture reading materials. The interview questions deal with discovering the students' preference and their response toward the use of local and target culture reading texts in English reading classes. During the interview, both the questions being asked and the students' responses were recorded. There were 10open-ended questions and could be seen as follows:

1. In your opinion, which one do you prefer: English reading text with source/local culture or target culture?

2. Why do you think so?

3. In what way does local or target culture text help you?
4. What factors do you think affect your reading comprehension? (Knowledge of the grammar/structure of the language, knowledge of the topic/ content, knowledge of the vocabulary, or others)?

5. Which of those factors influence you the most?

6. To what extent do you think the most influential factor helps your reading comprehension?

7. What are the benefits of reading an English text from source/ local culture?

8. What are the benefits of reading an English text from target culture?

9. In your opinion, which culture should be taught along with English language teaching

10. Why do you think so?

After all the data were collected, they were analyzed by using descriptive qualitative analysis on the questionnaire and the interview. The data collected from the Likert-scale in the questionnaire were compiled and analyzed. Then, the responses from the interview were transcribed and analyzed. Finally, we triangulated information collected during and after the data were gathered from the various participants to confirm findings.

\section{RESULTS AND DISCUSSIONS}

The findings are divided into two sections. The first section discusses the findings for students' responses regarding the cultural elements and the second section covers the findings for students' responses deal with the content of the texts in terms of the level of difficulty and the level of interest of the texts. 


\section{Students' responses regarding the cultural elements}

The findings for the cultural elements suggested that the all of the students agreed that both local culture and target culture should be taught along with English language teaching. However, there were a considerable number of different responses that were elicited from the interview.

The common reasons provided by the participants for their agreement on the inclusion of target culture in English language teaching were that language and culture cannot be separated from each other and that learning target culture can give more information about native English speaking countries. These findings are in line with the ideas of Byram and Flemming (1998) regarding the use of target culture in English language teaching.

As for the reasons why the students also agreed on the teaching of local culture, most of them $(80 \%)$ admitted that reading local culture texts increases their confidence to talk about their own culture when they have conversation with friends from different countries. Meanwhile, the rest of them (20\%) emphasized the necessity of using local culture materials along with English language teaching to preserve their own culture and identity. The findings support what has been suggested by Cortazzi \& Jin (1999), McKay (2003a) and Miftah (2013) regarding the clear advantages for the use local culture content. In fact, McKay (2003a, p.19) adds that "such content minimizes the potential of marginalizing the values and lived of experiences of the learners".
Moreover, it is interesting to find out that despite the agreement of all respondents toward the use of both local and target culture materials, a significant number of students (45\%) think that other culture such as those that are not from English speaking countries and Indonesia should also be included in English language teaching. The reasons were due to today's role of English as an international language in which English is not only spoken and used by native speakers of English, but also used by speakers whom English is not their mother tongue. The results bolster the importance of the use of international culture in English language teaching (Cortazzi \& Jin, 1999 and McKay, 2003a). Also, the recognition of using international culture are in accordance with McKay (2003a) as she argues that it is time to recognize the multilingual context of English use due to the shift in the nature of English.

\section{Students' responses regarding the content of the texts}

In relation to how students perceive both local and target culture regarding the content of the texts, the data gained from the questionnaire and the interview show that majority of them prefer English reading texts with target culture. However, the explanations for the students' responses regarding the content of the texts are discussed in terms of level of difficulty of the texts and level of interest of the texts, and can be seen in the following sections.

\section{a. Students' responses on the level of difficulty of the texts:}

The following chart displays the result of the 


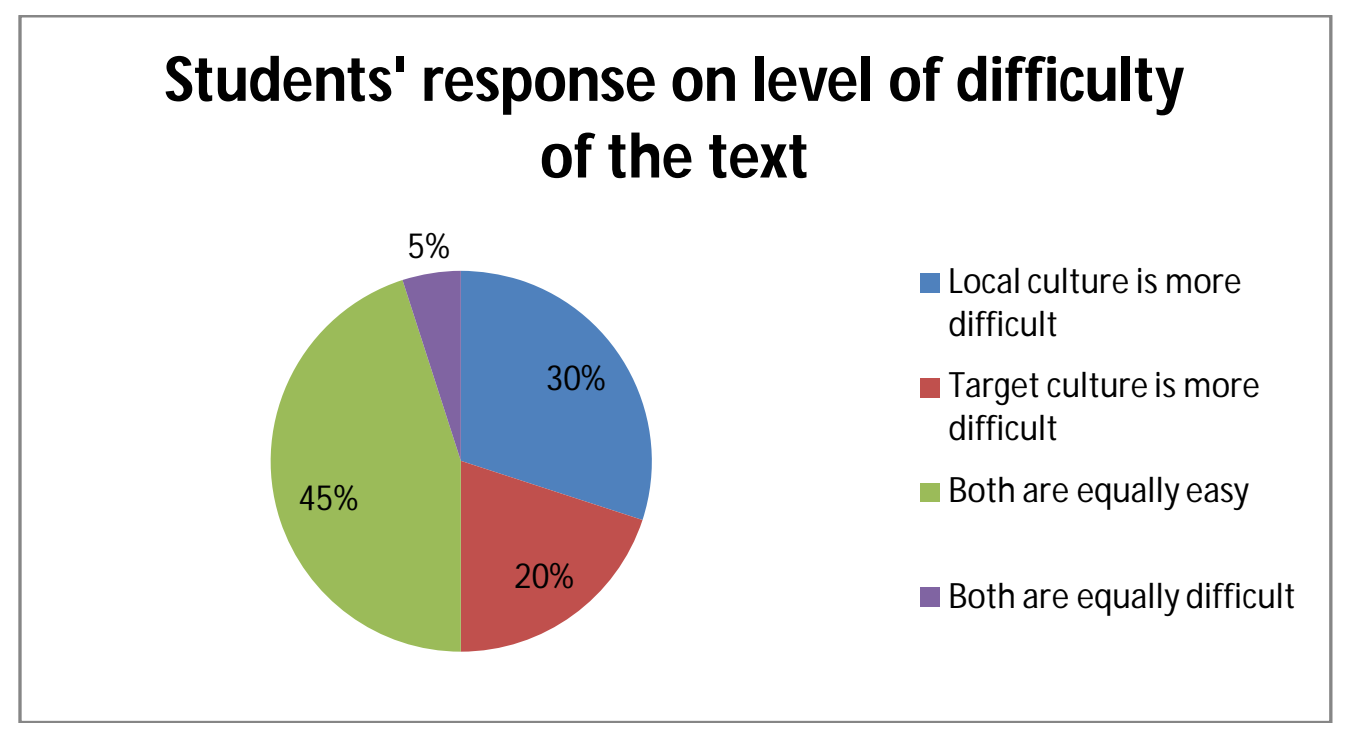

From the chart above, it is interesting to find out that, despite its unfamiliar content, almost half of the respondents think that the both texts are equally easy. In terms of target culture, only $20 \%$ of the students think that they are difficult. Most students consider the local culture materials are not easier than the target culture materials. This, according to the students, is caused by the use of complex grammar and unfamiliar words in the texts. They perceive the texts as more academic than the target culture texts which are more popular in style. However, their background knowledge or knowledge of the topic can help them understand the texts better. These findings support what have been suggested by Luke and Freebody
(1990) who consider readers not only as code breakers, but also as text participants, text users and text analyst. As text participants, readers connect the texts with their background knowledge, including knowledge of the world, cultural knowledge, and knowledge of the generic structure. The importance of background knowledge is also underlined by Fisher and Frey (2009) who claim that background knowledge has a profound influence on students' ability to comprehend what they read.

b. Students' responses on the level of interest of the texts:

The following chart displays the result of the questionnaire: 


\section{Students' responses on level of interest of the texts}

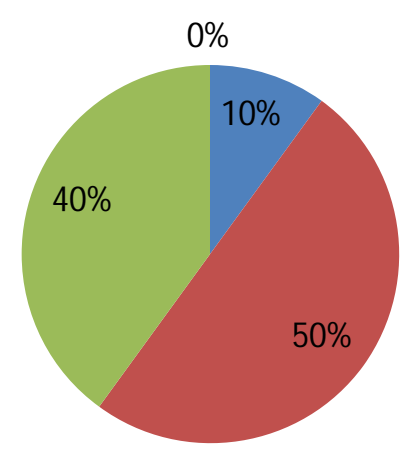

- Local culture text is interesting

- Target culture text is interesting

Both culture text are interesting

Neither texts are interesting

Regarding whether the texts are interesting or not, a significant number of students (40\%) admitted that both local and target culture texts are quite interesting. In their opinion, reading local culture materials is interesting because they can learn more about their own culture. They also stated that it is essential for students to know about their own culture so that it can raise their awareness of their home culture. Besides, their familiarity with the topic helps them guess the difficult words found in the texts. When asked about the target culture reading materials, the data from the interview reveal that the materials are interesting because they talk about something new to them and can broaden their horizons.

Yet, the chart also show that $50 \%$ of the students perceived that the target culture texts are more interesting, and only few of the students think that the local culture materials are interesting. The common reasons for choosing target culture texts were because the vocabulary and the sentence structure used in the texts are quite simple that they did not find any significant difficulty understanding the texts. This means, their linguistic knowledge supports their understanding of the texts. Other reasons for choosing target culture were that target culture reading texts are more interesting and are more convenient to read. Those who think that local culture reading materials are less interesting comment that the topics are already familiar to them; therefore, they do not find something new in the texts. Besides, they think that the local culture reading materials tend to use more complex grammar and vocabulary which make it more difficult to understand the texts.

Overall, the students seem to prefer to read reading texts with target culture content to local culture content despite their unfamiliarity with the topics. Some of the reasons are because learning target culture contents, most of which are new to them, means widening their knowledge and horizons. Yet, the findings regarding the content of the texts, both in terms of level difficulty and level of the interest of the texts suggested that both kinds of texts are useful and hence it will be good if both texts are used along with English language teaching because they have to balance their knowledge of each culture. Moreover, they also consider learning aspects of other cultures as worthwhile activity. Thus, giving 
reading materials containing different cultures can improve their cross cultural understanding and at the same time avoid boredom.

\section{CONCLUSION}

The outcome of this small scale survey highlights different attitudes which are perceived by the students regarding their preference towards the use of cultural content of reading materials in the classroom. Although reading in a foreign language requires several kinds of knowledge such as knowledge of the topic, knowledge of the structure of the language, and vocabulary knowledge, students have different perception about the content of reading materials they prefer to use in the classroom. They seem to prefer target culture reading materials due to the consideration that they are more interesting and convenient to read and their relative understanding of the sentence structure and vocabulary. However, the result of the study also indicates that both the source culture and the target culture serve a useful purpose in Indonesian English classes. This is in line with McKay's (2009b) findings that both local and target culture give significant impact in EFL classes. Given the fact that the nature of English has shifted, most of the students acknowledge the importance of using international culture materials in English language teaching. With regard to today's role of English as an international language in which it requires awareness that to a large extent, English has become denationalized, teachers; therefore, can facilitate this by alternating the use of target, local, and international culture reading materials to accommodate students' interest on the one hand, and on the other, to promote their awareness of a variety of cultures, including their own local culture as one of the ways to develop cross-cultural understanding among students in multilingual context of English use with regard to today's role of English as an international language.

\section{ACKNOWLEDGEMENTS}

We would like to express our sincere gratitude to journal Bahasa \& Sastra for publishing this article, and the same goes to those who have helped this research.

\section{REFERENCES}

Anderson,R. \&Pearson, P. 1984. "A Schema-theoretic View of Basic Processes in Reading Comprehension." In P. Pearson (Ed.), Handbook of Reading Research, New York: Longman.

Byram, M. \&Flemming, M. (Eds.) 1998.Language Learning from an Intercultural Perspective. Cambridge: Cambridge University Press.

Cobuild, C.2006. Dictionary. Australia: Collins Cobuild.

Cortazzi, M., \& Jin, L. 1999. "Cultural mirrors: Materials and methods in the EFL classroom". In E. Hinkel (Ed.), Culture in second language teaching and learning (pp. 196-219). Cambridge: Cambridge University Press.

Creswell. J.W. 2007. Available online http://www.sagepub.com/upmdata/22780_Chapter_1.pdf.

Crystal, D.1997. English as a Global Language. Cambridge: Cambridge University Press.

Fisher, D. \& Frey, N.2009.Background Knowledge: the Overlooked Factor 
in Reading Comprehension. New York: McGraw Hill Education.

Gibbons, P.2002. Scaffolding Language, Scaffolding Learning: Teaching Second Language Learners in the Mainstream Classroom. NH: Heinemann.

Holliday, A.2009. "English as a Lingua Franca, 'Non-native Speakers' and Cosmopolitan Realities". In F. Sharifian (Ed.), English as an International Language: Perspectives and Pedagogical Issues (pp.21-33). Bristol: Multilingual Matters, St Nicholas House.

Jenkins, J. 2006."Current Perspectives on TeachingWorldEnglishes and English as a Lingua Franca". TESOL Quartertly, 40 (1), pp.157-181.

Lin, Z.2002. 'Discovering EFL Learners' Perception of the Prior Knowledge and its Roles in Reading Comprehension". Journal of Research in Reading, 25(2), pp.

Llurda, E. 2009. “Attitudes Towards English as an International Language: The pervasiveness of native Models Among L2 Users and Teachers". In F. Sharifian (Ed.), English as an International Language: Perspectives and Pedagogical Issues (pp.119-134). Bristol: Multilingual Matters, St Nicholas House.

Luke, A. \& Freebody, P.1990. "Literacies' Programs: Debate and Demands in Cultural Context". Prospect 5(3), pp.7-16.

McKay, S. L.2003a. "Toward An Appropriate EIL Pedagogy: Reexamining Common ELT
Assumption". International Journal of Applied Linguistics, 13(1), pp. 122.

McKay, S. L. 2003b. "EIL curriculum development". RELC Journal, 34(1), pp. 31-47.

McKay, S. L.2009a. "Pragmatics and EIL Pedagogy". In F. Sharifian (Ed.), English as an International Language: Perspectives and Pedagogical Issues (pp.227-241). Bristol: Multilingual Matters, St Nicholas House.

McKay, S. L.2009b. "Source Culture or Target Culture. CAPE Teacher Talk 43".

From http://www.cape.edu/teachertalk.htm 1 .

Miftah, R.2013. "The Use of Local Culture Texts for Enthusiastic English Reading Teaching". The International Journal of Social Science, 7(1), pp. 130-135.

Robert, P. and Canagarajah, S. 2009. "Broadening the ELF Paradigm: Spoken English in an International Encounter". In F. Sharifian (Ed.), English as an International Language: Perspectives and Pedagogical Issues (pp.209-226). Bristol: Multilingual Matters, St Nicholas House.

Seidlhofer, B.2004. "Research perspectives on teaching English as a lingua franca". Annual Review of Applied Linguistics, 24, pp.209-239.

Seidlhofer, B. 2005. "Key concepts in ELT: English as a lingua franca". ELT Journal, 59 (4), pp. 339-341. 
Sharifian, F.2009. "English as an International Language". In F. Sharifian (Ed.), English as an International Language: Perspectives and Pedagogical Issues (pp.1-20). Bristol: Multilingual Matters, St Nicholas House.

Sonda, N.2011. "Japanese college students' attitudes towards English as an international language: A structural equation modeling analysis". In A. Stewart (Ed.), JALT 2010 Conference Proceedings. Tokyo: JALT.

Wallace, C.1992. Learning to Read in a Multicultural Society: The Social
Context of Second language Literacy. New York: Prentice Hall.

Yilmaz, D.2010. "Culture in English Language Classroom: What do students think?", Unpublished Research Project Paper,TUBITAK The Scientific and Technological Research Council of Turkey, Bogaziçi University, Turkey.

Zacharias, N.2005. 'Teachers' Beliefs about Internationally-Published Materials: A Survey of Tertiary English Teachers in Indonesia". RELC Journal, 36(23), pp. 23-37. 